\title{
The new ELN Recommendations for treating CML. Early transplantation in patients with high-risk ACA
}

\author{
Rüdiger Hehlmann \\ Medical Faculty Mannheim, Heidelberg University; ELN Foundation Weinheim, Germany \\ Prof. Dr. Rüdiger Hehlmann, Medical Faculty Mannheim, \\ E-mail: Hehlmann.eln@gmail.com \\ Heidelberg University; ELN Foundation Weinheim, Germany
}

Citation: Hehlmann R. The new ELN recommendations for treating CML. Early transplantation in patients with high-risk ACA. Cell Ther Transplant 2020; 9(4): 11-19.

\section{Summary}

After 150 years of mostly palliative CML therapy, treatment advances with BCR-ABL1 tyrosine kinase inhibitors (TKI) have resulted in normal survival for most patients with CML. The new treatment goal is treatment-free remission (TFR) with survival at good quality of life without life-long treatment. The European LeukemiaNet (ELN) has accounted for this development with its most recent recommendations. Hematopoietic stem cell transplantation has retained an important role in patients who have become resistant or intolerant to all TKI or progress to advanced phases.
This review focuses on the ELN 2020 recommendations for treating CML and on early transplantation in highrisk patients.

\section{Keywords}

Chronic myeloid leukemia, high-risk group, tyrosine kinase inhibitors, hematopoietic stem cell transplantation, ELN recommendations.

\section{Introduction}

Since the first attempts at treating CML with arsenic in 1865, treatment has been mostly palliative. Some modest prolongation of survival was reported with hydroxyurea and interferon alpha, for review see Hehlmann (2020) [1]. The only curative approach was allogeneic transplantation which, however, was available only to those few patients who had a donor and could tolerate the procedure. The advent of tyrosine kinase inhibitors has profoundly changed CML management as normal survival has been achieved for most patients as seen from Table 1 [2-11]. The new goal for treating CML is now survival at good quality of life without life-long treatment: treatment discontinuation in sustained deep molecular remission (DMR) and treatment-free remission (TFR). The European LeukemiaNet (ELN) has accounted for this development with an update of its recommendations [12]. This review summarizes the most important new developments and recommendations for treating CML including early transplantation of patients with high-risk additional chromosomal abnormalities (ACA) in early CML end-phase [13].

\section{Diagnosis}

At diagnosis, ELN recommends a complete blood count with microscopic differential and a physical examination with special reference to spleen and liver size. Marrow cytology, cytogenetics for securing the Philadelphia $(\mathrm{Ph})$ chromosome and a qualitative polymerase chain reaction (PCR) for BCRABL1 transcripts detection and typing are also recommended as well as an EKG, standard clinical chemistry and a hepatitis serology [12].

\section{Risk score}

The preferred risk score is the new EUTOS score for longterm survival (ELTS), since it predicts death by CML better than all other scores $[14,15]$. ELTS uses the same variables as the Sokal score, but with different weights. Age is much less important in the TKI era, since TKI treatment is virtually equally successful in older patients. The variables of the ELTS score and the calculation of relative risk are shown in Table 2. 
Table 1. Survival of CML patients in clinical trials: update 2020

\begin{tabular}{|c|c|c|c|c|c|c|}
\hline Study & Dose, mg & $\mathbf{n}$ & $\begin{array}{l}\text { Age at diagnosis, } \\
\text { median, years }\end{array}$ & $\begin{array}{l}\text { 5-year } \\
\text { survival, \% }\end{array}$ & $\begin{array}{l}10 \text {-year } \\
\text { survival, \% }\end{array}$ & $\begin{array}{l}\text { Median observation } \\
\text { time, years }\end{array}$ \\
\hline CML-IV ${ }^{2}$ & IM 400-800 & 1536 & 53 & 90 & 82 & 9.5 \\
\hline $\mathrm{IRIS}^{3}$ & IM 400 & 553 & 50 & 89 & 83.3 & 10.9 \\
\hline $\mathrm{MDACC}^{4}$ & $\begin{array}{l}\text { IM } 400 \\
\text { IM } 800\end{array}$ & $\begin{array}{l}70 \\
201\end{array}$ & 48.3 & NR & $\begin{array}{l}80 \\
84\end{array}$ & $\begin{array}{l}9.9 \\
(\min .8)\end{array}$ \\
\hline French Spirit $^{5}$ & IM 400-600 & 787 & 51 & NR & 85 & 10 \\
\hline ENESTnd $^{6}$ & $\begin{array}{l}\text { IM } 400 \\
\text { Nilo } 600\end{array}$ & $\begin{array}{l}283 \\
282\end{array}$ & $\begin{array}{l}46 \\
47\end{array}$ & $\begin{array}{l}92 \\
94\end{array}$ & $\begin{array}{l}88.3 \\
87.6\end{array}$ & 10 \\
\hline Dasision ${ }^{7}$ & $\begin{array}{l}\text { IM } 400 \\
\text { Dasa } 100\end{array}$ & $\begin{array}{l}260 \\
259\end{array}$ & $\begin{array}{l}49 \\
46\end{array}$ & $\begin{array}{l}90 \\
91\end{array}$ & NA & 5 \\
\hline Bfore $^{8}$ & $\begin{array}{l}\text { IM } 400 \\
\text { BOS } 400\end{array}$ & $\begin{array}{l}268 \\
268\end{array}$ & $\begin{array}{l}53 \\
52\end{array}$ & $\begin{array}{l}94.6 \\
94.5\end{array}$ & NA & 5 \\
\hline $\begin{array}{l}\text { Median } \\
\text { (estimate) }\end{array}$ & & & & 92 & 84 & \\
\hline
\end{tabular}

Note: $\mathrm{IM}=$ imatinib, Nilo = nilotinib, Dasa $=$ dasatinib, $\mathrm{BOS}=$ bosutinib, NA = not assessed

Table 2. Risk assessment by ELTS ${ }^{14}$

\begin{tabular}{|c|c|c|}
\hline Calculatio & & Definition of risk groups \\
\hline $\begin{array}{l}0.0025 \\
+0.0615 \\
+0.1052 \\
+0.4104\end{array}$ & $\begin{array}{l}\times(\text { age } / 10)^{3} \\
\times \text { spleen size } \\
\times \text { blood blasts } \\
\times(\text { platelet count } / 1000)^{-0.5}\end{array}$ & $\begin{array}{l}\text { Low risk: }<1.5680 \\
\text { Intermediate risk: 1.5680- } 2.2185 \\
\text { High risk: > 2.2185 }\end{array}$ \\
\hline
\end{tabular}

To calculate the ELTS scores go to: http://www.leukemia-net.org/content/leukemia/cml/elts score/index_eng.html

Table 3. Response milestones expressed as \% BCR-ABLI ${ }^{15}$

\begin{tabular}{|l|l|l|l|}
\hline Time & Optimal & Warnings & Failure \\
\hline Baseline & - & $\begin{array}{l}\text { High-risk ACA } \\
\text { high-risk ELTS score }\end{array}$ & - \\
\hline 3 months & $\leq 10 \%$ & $\begin{array}{l}>10 \% \\
\text { unconfirmed }\end{array}$ & $\begin{array}{l}>10 \% \\
\text { if confirmed within } 1-3 \text { months }\end{array}$ \\
\hline 6 months & $\leq 1 \%$ & $>1-10 \%$ & $>10 \%$ \\
\hline 12 months & $\leq 0.1 \%$ & $>0.1-1 \%$ & $>1 \%$ \\
\hline Anytime & $\leq 0.1 \%$ & $>0.1-1 \%$, \\
Loss of $\leq 0.1 \%($ MMR) & $>1 \%$ \\
\hline
\end{tabular}

${ }^{\star}$ Loss of MMR indicates failure after treatment-free remission (TFR)

\section{Molecular monitoring, response milestones and deep molecular response}

Molecular monitoring has replaced cytogenetics in clinical routine and is considered mainstay of treatment monitoring. Cytogenetics is still needed in the case of atypical translocations or atypical transcripts that cannot be measured by standard PCR, and in the case of failure/resistance or progression for detecting additional chromosomal abnormalities (ACA).
Quantitative real-time PCR (RT-PCR) should be performed on blood cells by standard methodology and reported as \% BCR-ABL1 transcripts on the international scale (IS) $[16,17]$. BCR-ABL1 in $\%{ }^{\mathrm{IS}}$ underlies the response milestones guiding treatment (Table 3).

Deep molecular responses (DMR; $\mathrm{MR}^{4}$ or deeper) indicate a state of disease with a very low probability of progress [18]. They are observed in the majority of TKI treated patients. 
Benchmark times for what can be expected have been determined in imatinib treated patients and are depicted in Fig. 1. Most molecular responses are stable. After 10 years, $92 \%$ of patients in MMR reached $\mathrm{MR}^{4.5}, 88 \%$ in $\mathrm{MR}^{4}$ reached $\mathrm{MR}^{5}$. Only one of 1326 patients in $\mathrm{MR}^{4}$ progressed during a median of 3.8 years, and none of 1302 patients in $\mathrm{MR}^{4.5}$ during a median of 3 years [18].

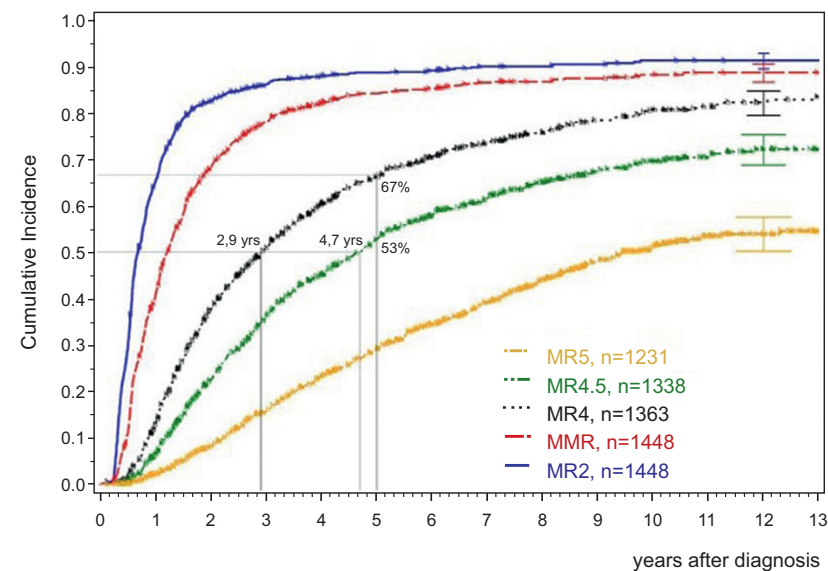

Figure 1. Benchmark times for molecular responses with imatinib (updated from Kalmanti et al.) [19]

Failure or intolerance (not for not-reaching MMR) in imatinib treated patients with treatment change to $2 \mathrm{G}$-TKI were observed in $26.5 \%$ over 9.5 years after a median of 34 months [2]. Changing treatment identified patients who did worse than the rest of the cohort, thus representing a poorer risk group. Most imatinib-treated patients, however, are candidates for treatment discontinuation.

\section{First-line treatment}

At present, 4 drugs are approved for $1^{\text {st }}$ line therapy in CML by EMA and FDA:

- imatinib;

- dasatinib;

- nilotinib;

- bosutinib.

Approved in Korea only:

- radotinib.

Generic imatinib, now available worldwide, is the cost-effective initial therapy in chronic phase (CP) CML. Dosing of generics should be the same as brand dosing. Patients should continue the same generic brand in order to avoid potential side-effects due to changes in drug structure, bioavailability and drug preparation [12].

\section{Second- and higher-line treatment}

Second and higher lines of treatment after intolerance or resistance to the first-line TKI usually also consist of a TKI, but may include allogeneic transplantation of hematopoietic cells (allo-HCT), see below.

In the instance of treatment failure/resistance or progression to accelerated phase or blast crisis a mutational analysis should be initiated (Table 4) and the treatment changed. If available, next-generation sequencing (NGS) should be used for mutational analysis $[12,20]$. Imatinib resistance muta-
Table 4. TKI drugs recommended in case of BCR-ABL1 resistance mutations

\begin{tabular}{|l|l|}
\hline F317L/V/I/C, T315A & $\begin{array}{l}\text { Nilotinib, bosutinib or } \\
\text { ponatinib }\end{array}$ \\
\hline V299L & Nilotinib or ponatinib \\
\hline Y253H, E255V/K, F359V/I/C & $\begin{array}{l}\text { Dasatinib, bosutinib or } \\
\text { ponatinib }\end{array}$ \\
\hline T315I & Ponatinib \\
\hline
\end{tabular}

tions are relatively rare in $\mathrm{CP}^{2}$, but are more frequent in advanced phases.

If 2G-TKI are applied, the following comorbidities and contraindications have to be considered:

- Dasatinib:

- Previous pleuro-pulmonary diseases are strong contraindications (cave pleural effusion).

- Uncontrolled hypertension, pulmonary arterial hypertension (PAH) and bleeding due to impaired platelet function (cave anticoagulation) are relative contraindications.

- Nilotinib:

- Coronary heart disease, cerebrovascular accidents and peripheral arterial occlusive disease represent strong contraindications.

- Also, hypertension, diabetes mellitus, hypercholesterolemia and a history of pancreatitis may represent contraindications.

- Bosutinib:

- No relevant comorbidities have been determined yet. Frequent and annoying, but mostly self-limited diarrhea occurs. Loperamide may be indicated.

- Ponatinib:

- Ponatinib is a third generation (3G-)TKI and the only TKI with activity against the T315I mutation.

- Because of its cardiotoxicity dosing is critical. An initial dose of $45 \mathrm{mg} /$ day should be reduced to a lower dose (15 mg/day) as soon as a response has been achieved [21].

\section{Allogeneic transplantation}

Although drug therapy is clearly superior to transplantation in CP [22], transplantation still plays an important role in CML treatment. Indications have moved from CP to more advanced phases, accelerated phase (AP) and blast crisis (BC), but transplantation in CP has to be considered in highrisk patients. Transplantation in $\mathrm{CP}$ is still indicated in:

- TKI resistant disease

- Rare patients who are intolerant to all currently available TKI

- Resistance to initial 2G-TKI

- Resistance to 3G-TKI indicating high risk of progression

- End-phase CML with high-risk ACA.

Fig. 2 illustrates the management of progression and emerging $\mathrm{AP}$ and $\mathrm{BC}^{1}$. Outcome of transplantation in $\mathrm{AP}$ and $\mathrm{BC}$ is worse than in $\mathrm{CP}$, but transplantation provides probably 


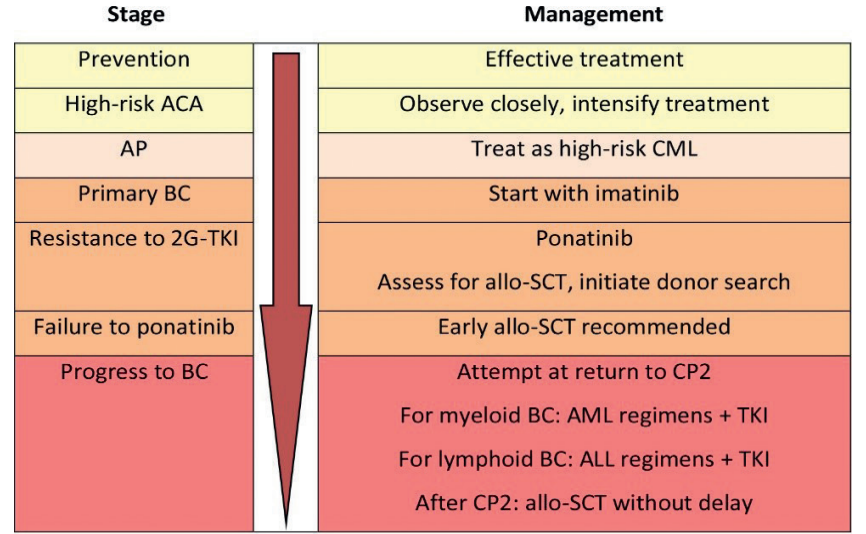

The red arrow indicates progression to the worse. $\mathrm{CP} 2=$ second chronic phase

Figure 2. Clinical strategies in evolving acceleration phase and blast crisis of CML

the best outcome in BC. In an analysis of 786 BC patients managed by the German CML Study Group, 29 of the 40 long-term survivors (72.5\%) had received a transplant [23].

Since earlier transplantations have better outcomes [23], the strategy is to recognize emerging progression to $\mathrm{BC}$ earlier. High-risk ACA indicate emerging progression. High-risk ACA are observed with increasing frequency in the later course of CML and have a negative impact on survival (Fig. $3)$. High-risk ACA are as follows [13, 24-26]:

$\bullet+8$

$\cdot+\mathrm{Ph}$

$\cdot \mathrm{i}(17 \mathrm{q})$

$\bullet+19$

$\cdot+21$

$\bullet+17$

$\cdot-7 / 7 \mathrm{q}-$

- 3q26.2

- 11q23

- complex karyotypes (3 or more aberrations).
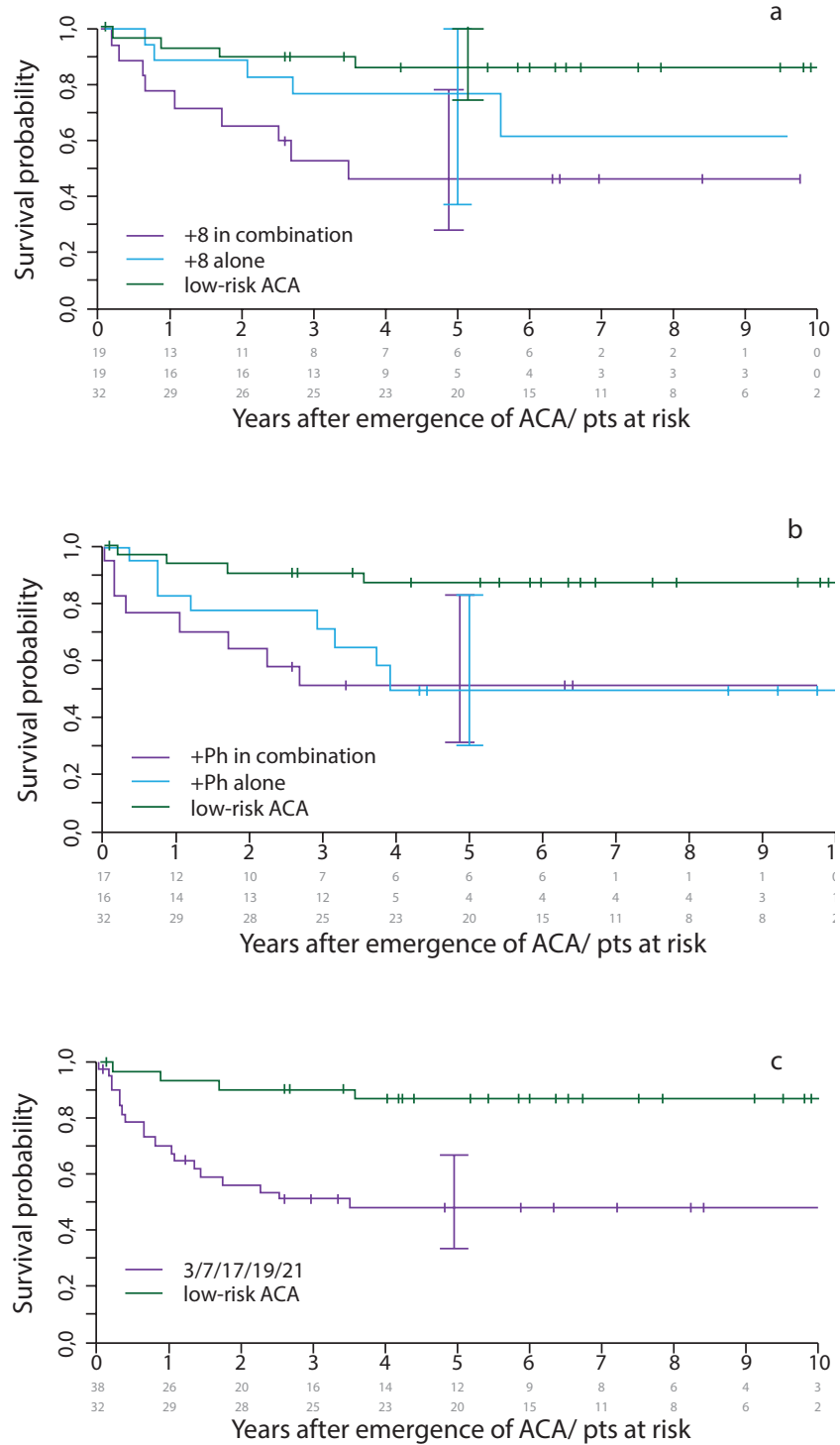

Figure 3. Survival in CML patients with high-risk vs low-risk ACA

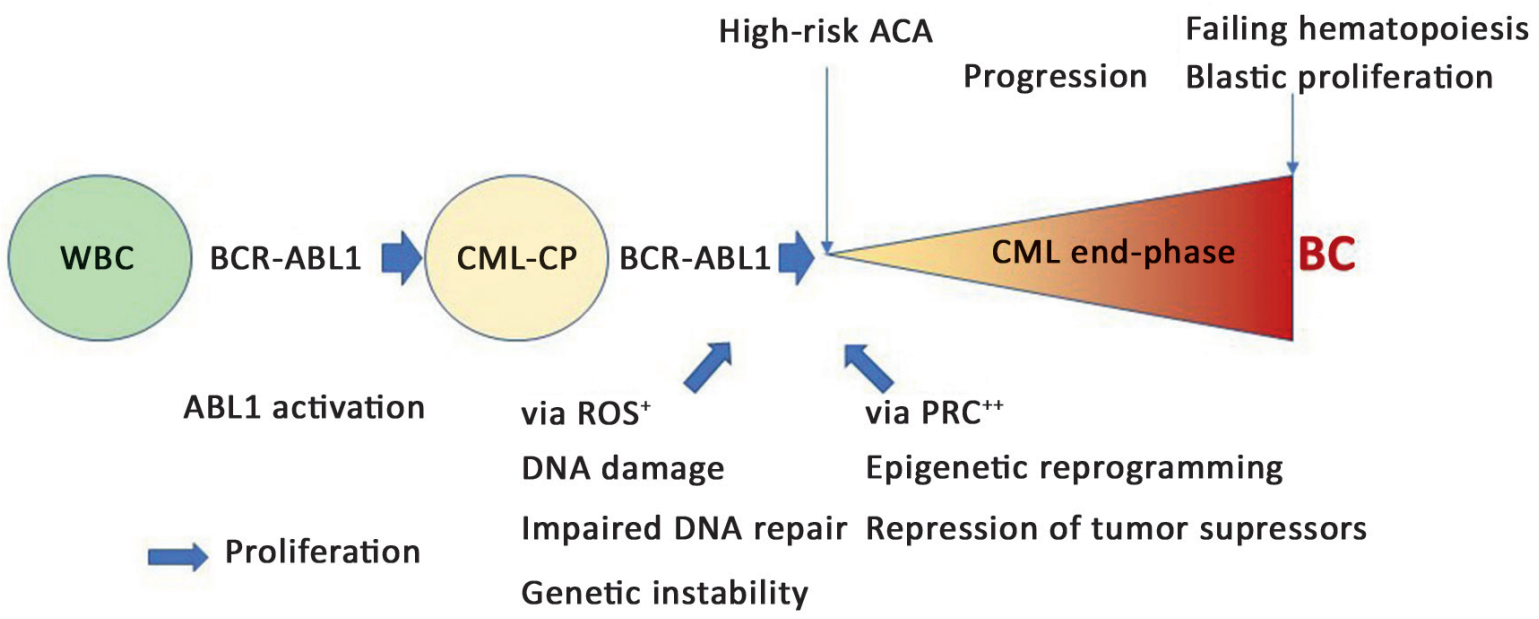

+ ROS = reactive oxygen species $++\mathrm{PRC}=$ polycomb repressing complex

Figure 4. High-risk ACA and progression to blast crisis [13, 27, 28] 
High-risk ACA are used to define CML end-phase. CML end-phase comprises early progression with emerging highrisk ACA and late progression with failing hematopoiesis and blast proliferation (Fig. 4).

A total of 42 patients with high-risk ACA were transplanted in CML Study IV. Transplantation in early CML end-phase with emerging high-risk ACA, but without progression to AP or BC has shown superior survival (Fig. 5), although the survival difference, due to the small numbers $(n=13$ without progression; $n=26$ with progression to $A P$ or $B C ; n=3$ phase unknown), has not reached statistical significance at $\mathrm{p}=0.09$ [13].

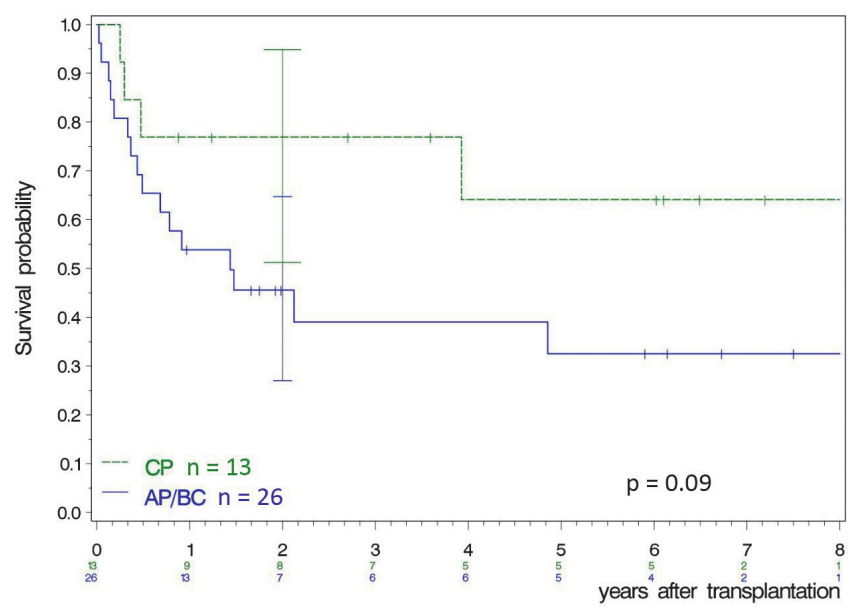

Figure 5. Early versus late transplantation in CML patients with high-risk ACA [13]

High-risk ACA at low blast counts herald death by CML [13]. The hazard to die with high-risk ACA compared with no ACA is increased:

- Up to 3.9-fold at blood blast levels of 1-5\%;

- Up to 6.5 -fold at marrow blast levels of 1-15\%.

The lower the blast count, the higher is the predictive power of high-risk ACA. Low-risk ACA are associated with lesser or non-increased hazard.

\section{Treatment discontinuation and TFR}

Achievement of TFR after treatment discontinuation in sustained DMR is a new goal in the management of CML[12]. The majority of imatinib-treated patients in $\mathrm{CP}$ have reached DMR (MR4 or deeper) after 3 years as seen from Fig. 1 [18, 19]. Benchmark times for DMR have been determined in long-term clinical trials for imatinib [2], dasatinib [7], nilotinib [6], and bosutinib [8] and are shown in Table 5.

After the first pioneering studies have been published by the French CML group [29,30] many more studies have followed. Table 6 shows a selection of 21 studies totaling close to 3000 patients. Rates of relapse-free remissions at 2 years range around $50 \%$ (33\% to $72 \%$ at $0.5-10$ years). The largest of the studies, the EURO-SKI study $(\mathrm{n}=755)$, reports a TFR rate of $49 \%$ at 2 years [31].

Duration of TFR and of TKI treatment appear to be the most important predictors of successful TFR [31]. Loss of
Table 5. Benchmark times for DMR $\left(M^{4}, M R^{4.5}\right)$

\begin{tabular}{|c|c|c|c|}
\hline Study & & $\begin{array}{l}5 \text { years } \\
(\%)\end{array}$ & $\begin{array}{l}10 \text { years } \\
(\%)\end{array}$ \\
\hline \multirow{2}{*}{$\begin{array}{l}\text { CML-Study IV* } \\
{[18,19]}\end{array}$} & Imatinib MR ${ }^{4}$ & 68 & 81 \\
\hline & Imatinib MR ${ }^{4.5}$ & 53 & 72 \\
\hline \multirow[t]{4}{*}{ ENESTnd **[6] } & Nilotinib MR & 66 & 73 \\
\hline & Nilotinib MR ${ }^{4.5}$ & 54 & 64 \\
\hline & Imatinib MR $^{4}$ & 42 & 56 \\
\hline & Imatinib MR ${ }^{4.5}$ & 35 & 45 \\
\hline \multirow[t]{2}{*}{ Dasision $* \star \star[7]$} & Dasatinib MR ${ }^{4.5}$ & 42 & NA \\
\hline & Imatinib MR ${ }^{4.5}$ & 33 & NA \\
\hline \multirow[t]{4}{*}{ Bfore $* \star \star \star[8]$} & Bosutinib MR & 58 & NA \\
\hline & Bosutinib MR ${ }^{4.5}$ & 47 & NA \\
\hline & Imatinib $\mathrm{MR}^{4}$ & 48 & NA \\
\hline & Imatinib MR ${ }^{4.5}$ & 37 & NA \\
\hline
\end{tabular}

Notes: ${ }^{*}$ imatinib $(\mathrm{n}=1442),{ }^{* *}$ nilotinib $300 \mathrm{mg}$ twice daily $(\mathrm{n}=282)$, imatinib $400 \mathrm{mg}$ daily $(\mathrm{n}=283),{ }^{* *}$ dasatinib $100 \mathrm{mg}$ once daily $(\mathrm{n}=259)$, imatinib $400 \mathrm{mg}$ daily $(\mathrm{n}=260),{ }^{* * *}$ bosutinib $400 \mathrm{mg}$ once daily $(\mathrm{n}=268)$, imatinib $400 \mathrm{mg}$ daily $(\mathrm{n}=268), \mathrm{NA}=$ not available

DMR rates of these trials cannot be directly compared owing to different methods of trial evaluation.

MMR indicates failure after TFR [32]. After resumption of treatment, $95 \%$ of patients will regain pre-discontinuation response levels.

The ELN considers the following requirements mandatory for TKI discontinuation [12]:

- CML in first CP only (data are lacking outside this setting);

- motivated patient with structured communication;

- accessibility to high quality quantitative PCR using the International Scale (IS) with rapid turn-around of PCR test results;

- patient agreement to more frequent monitoring after stopping treatment meaning;

- monthly for the first 6 months, every 2 months for months 6-12, and every 3 months thereafter.

\section{Conclusion}

By 2020, survival of patients with CML has approached that of the general population. ELTS score is the preferred risk score in the TKI era. Molecular monitoring of minimal residual disease has replaced cytogenetics in routine monitoring. The four TKIs available for first-line therapy show different adverse effects profiles, but no differences in survival. Generic imatinib is the cost-effective initial treatment in chronic phase CML. Usage of second and higher-line TKI therapy is specified by mutational analysis and comorbidities. Early allogeneic hematopoietic cell transplantation is indicated in 
Table 6. Selected TKI-discontinuation studies, update 2020

\begin{tabular}{|c|c|c|c|c|c|c|c|}
\hline Study & TKI & $\begin{array}{l}\text { Min. } \\
\text { treatment } \\
\text { duration } \\
\text { (years) }\end{array}$ & $\mathrm{n}$ & $\begin{array}{l}\text { Depth } \\
\text { of MR }\end{array}$ & $\begin{array}{l}\text { Min. } \\
\text { duration } \\
\text { of MR } \\
\text { (years) }\end{array}$ & $\begin{array}{l}\text { RFS with at least } \\
\text { MMR }\end{array}$ & References \\
\hline Euro-SKI & IM & 3 & 755 & $\mathrm{MR}^{4}$ & 1 & $49 \%$ at 2 years & Saußele et al, 2018 [31] \\
\hline STIM & IM & 2 & 100 & $\mathrm{MR}^{5}$ & 2 & $37 \%$ at 10 years & $\begin{array}{l}\text { Etienne et al, } 2017 \text { [33] } \\
\text { Update at ESH } 2019\end{array}$ \\
\hline TWISTER & IM & 3 & 40 & $\mathrm{MR}^{4.5}$ & 2 & $45 \%$ at 42 months & Ross et al, 2013 [34] \\
\hline A-STIM & IM & 3 & 80 & UMRD & 2 & $64 \%$ at 23 months & Rousselot et al, 2014 [32] \\
\hline KID study & IM & 3 & 126 & $M^{4.5}$ & 2 & $58 \%$ at 2 years & $\begin{array}{l}\text { Lee et al, } 2016 \text { [35] } \\
\text { Update Zang } 2018 \\
\text { ASH a. } 4252 \text { [36] }\end{array}$ \\
\hline STIM2 & IM & 2 & 200 & $\mathrm{MR}^{4.5}$ & 2 & $46 \%$ at 2 years & $\begin{array}{l}\text { Nicolini et al, } 2018 \text { [37] } \\
\text { ASH a. } 462\end{array}$ \\
\hline ISAV & IM & 2 & 112 & UMRD & 1.5 & $52 \%$ at 22 months & $\begin{array}{l}\text { Mori et al, } 2015 \text { [38] } \\
\text { Update at ASH } 2018 \text { a.461 } \\
\text { [39] }\end{array}$ \\
\hline STOP 2G-TKI & Dasa / Nilo & 2 & 60 & $\mathrm{MR}^{4.5}$ & 2 & ca. $55 \%$ at 4 years & Rea et al, 2017[40] \\
\hline DADI & Dasa $2^{\text {nd }}$ line & ND & 63 & $\mathrm{MR}^{4}$ & 1 & $49 \%$ at 6 months & Imagawa et al, 2015 [41] \\
\hline NILST & Nilo & 2 & 87 & $M^{4.5}$ & 2 & $59 \%$ at 1 year & $\begin{array}{l}\text { Kadowaki et al, } 2016 \\
\text { ASH a. } 790 \text { [42] }\end{array}$ \\
\hline TRAD & IM / Dasa & 3 & 75 & $\mathrm{MR}^{4.5}$ & 2 & $58 \%$ at 6 months & $\begin{array}{l}\text { Kim et al, } 2016 \\
\text { ASH a. } 1922[43]^{3}\end{array}$ \\
\hline Dasfree & Dasa & 2 & 84 & $M^{4.5}$ & 1 & $46 \%$ at 2 years & $\begin{array}{l}\text { Shah et al, } 2019 \text { [44] } \\
\text { Update at ESH } 2019\end{array}$ \\
\hline ENESTop & Nilo $2^{\text {nd }}$ line & 3 & 126 & $M^{4.5}$ & 1 & $58 \%$ at 4 years & $\begin{array}{l}\text { Hughes et al, } 2016 \\
\text { ASH a. } 792 \text { [45] }\end{array}$ \\
\hline STAT2 & IM / Nilo & 2 & 96 & $\mathrm{MR}^{4.5}$ & 2 & $68 \%$ at 1 year & Takahashi et al, 2018 [46] \\
\hline ENESTfreedom & Nilo & 2 & 190 & $M^{4.5}$ & 1 & $52 \%$ at 4 years & Hochhaus et al, 2017 [47] \\
\hline D-STOP & IM / Dasa & ND & 54 & $\mathrm{MR}^{4}$ & 2 & $63 \%$ at 1 year & $\begin{array}{l}\text { Kumagai et al, } 2016 \\
\text { ASH a. } 791 \text { [48] }\end{array}$ \\
\hline Spanish study & IM/Nilo/Dasa & 3 & 236 & $\mathrm{MR}^{4.5}$ & 2 & $64 \%$ at 4 years & $\begin{array}{l}\text { Boluda et al, } 2018 \\
\text { ASH a. } 47[49]\end{array}$ \\
\hline DESTINY & IM/Nilo/Dasa & $\begin{array}{l}6.9 \\
\text { (median) }\end{array}$ & 125 & $\mathrm{MR}^{4}$ & 3 & $72 \%$ at 3 years & Clark et al, 2019 [50] \\
\hline Routine Care & TKI & 7.1 & 128 & $\mathrm{MR}^{4}$ & 4 & $67 \%$ at 2,9 years & Rousselot et al, 2020 [51] \\
\hline $\begin{array}{l}\text { Swedish } \\
\text { CML-Registry }\end{array}$ & TKI (53\% IM) & 7.7 & 131 & DMR & $\begin{array}{l}2.9 \\
\text { (median) }\end{array}$ & $\begin{array}{l}61 \% \text { outside, } 35 \% \\
\text { inside a study at } 2 \\
\text { years }\end{array}$ & Richter, ESH 2020 \\
\hline RE-STIM & (2nd stop) & 3.1 (median) & 106 & $\mathrm{MR}^{4.5}$ & $\begin{array}{l}1.7 \\
\text { (median) }\end{array}$ & $33 \%$ at 4 years & $\begin{array}{l}\text { Legros et al, } 2017 \text { [52] } \\
\text { Update at EHA } 2019\end{array}$ \\
\hline Total: 21 & & & 2974 & & & $\begin{array}{l}33-72 \% \text { at } 0.5-10 \\
\text { years }\end{array}$ & \\
\hline
\end{tabular}

Notes: Updated from [1]. ND = not defined; UMRD = undetectable minimal residual disease; IM = Imatinib; Nilo = Nilotinib; Dasa = Dasatinib; $\mathrm{MR}=$ molecular response; $\mathrm{RFS}$ = relapse free survival. 
high-risk patients, e.g. with high-risk ACA. The new treatment goal is TFR. TKI discontinuation is feasible and safe. The rate of successful TFR ranges around $50 \%$ at 2 years.

\section{Conflict of interest}

None declared.

\section{References}

1. Hehlmann, R. Chronic Myeloid Leukemia in 2020. HemaSphere. 2020; 4(5): e468.

2. Hehlmann R, Lauseker $M$, Saußele S, Pfirrmann $M$, Krause S, Kolb HJ et al. Assessment of imatinib as first-line treatment of chronic myeloid leukemia: 10-year survival results of the randomized CML study IV and impact of nonCML determinants. Leukemia. 2017; 31(11):2398-2406.

3. Hochhaus A, Larson RA, Guilhot F, Radich JP, Branford $\mathrm{S}$, Hughes TP et al. Long-term outcomes of imatinib treatment for chronic myeloid leukemia. New Engl J Med. 2017; 376:917-927.

4. Sasaki K, Strom SS, O’Brien S, Jabbour E, Ravandi F, Konopleva $\mathrm{M}$ et al. Relative survival in patients with chronicphase chronic myeloid leukemia in the tyrosine-kinase inhibitor era: analysis of patient data from six prospective clinical trials. Lancet Haematol. 2015; 2:e186-e193.

5. ESH Update 2019 to: Preudhomme C, Guilhot J, Nicolini $\mathrm{F}$ et al. Imatinib plus peginterferon alfa-2a in chronic myeloid leukemia. N Engl J Med. 2010; 363:2511-2521.

6. Hughes TP, Saglio G, Larson RA, Kantarjian HM, Kim D-W, Issaragrisil S, et al. Long-term outcomes in patients with chronic myeloid leukemia in chronic phase receiving frontline nilotinib versus imatinib: Enestnd 10-year analysis. Blood. 2019; 134:2924-2924.

7. Cortes JE, Saglio G, Kantarjian HM, Baccarani M, Mayer J, Boqué $\mathrm{C}$ et al. Final 5-year study results of DASISION: the dasatinib versus imatinib study in treatment-naïve chronic myeloid leukemia patient trial. J Clin Oncol. 2016; 34:23332340 .

8. Brümmendorf TH, Cortes JE, Milojkovic D, Gambacorti-Passerini C, Clark RE, Le Coutre PD, et al. Bosutinib (BOS) versus imatinib (IM) for newly diagnosed chronic myeloid leukemia (CML): Final 5-year results from the BFORE trial. Blood. 2020; 136 (Supplement 1): 41-42.

9. Thielen N, Visser O, Ossenkoppele G, Janssen J. Chronic myeloid leukemia in the Netherlands: a population-based study on incidence, treatment, and survival in 3585 patients from 1989 to 2012. Eur J Haematol. 2016; 97(2): 145-154.

10. Bower H, Bjorkholm M, Dickman PW, Höglund M, Lambert PC, Andersson TM. Life expectancy of patients with chronic myeloid leukemia approaches the life expectancy of the general population. J Clin Oncol. 2016; 34(24): 2851-2857.

11. Welch HG, Kramer BS, Black WC. Epidemiologic signatures in cancer. N Engl J Med. 2019; 381(14): 1378-1386.
12. Hochhaus A, Baccarani M, Silver RT, Schiffer C, Apperley J F, Cervantes F et al. European LeukemiaNet 2020 recommendations for treating chronic myeloid leukemia. Leukemia. 2020; 34(4):966-984.

13. Hehlmann R, Voskanyan A, Lauseker M, Pfirrmann M, Kalmanti L, Rinaldetti $\mathrm{S}$ et al. High-risk additional chromosomal abnormalities at low blast counts herald death by CML. Leukemia. 2020; 34: 2074-2086.

14. Pfirrmann M, Baccarani M, Saußele S, Guilhot J, Cervantes F, Ossenkoppele G, et al. Prognosis of long-term survival considering disease-specific death in patients with chronic myeloid leukemia. Leukemia. 2016; 30(1), 48-56.

15. Pfirrmann M, Clark RE, Prejzner W, Lauseker M, Baccarani $\mathrm{M}$, Saussele $\mathrm{S}$, et al. The EUTOS long-term survival (ELTS) score is superior to the Sokal score for predicting survival in chronic myeloid leukemia. Leukemia. 2020; 34(8), 2138-2149.

16. Cross NCP, White HE, Müller MC, Saglio G, Hochhaus A. Standardized definitions of molecular response in chronic myeloid leukemia. Leukemia. 2012; 26:2172-2175.

17. Cross NCP, White HE, Colomer D, Ehrencrona H, Foroni L, Gottardi E, et al. Laboratory recommendations for scoring deep molecular responses following treatment for chronic myeloid leukemia. Leukemia. 2015; 29:999-1003.

18. Hehlmann R, Müller MC, Lauseker M, Hanfstein B, Fabarius A, Schreiber A, et al. Deep molecular response is reached by the majority of patients treated with imatinib, predicts survival, and is achieved more quickly by optimized high-dose imatinib: results from the randomized CMLstudy IV. J Clin Oncol. 2014; 32:415-423.

19. Kalmanti L, Saußele S, Lauseker M, Müller MC, Dietz CT, Heinrich L et al. Safety and efficacy of imatinib in CML over a period of 10 years: data from the randomized CMLstudy IV. Leukemia. 2015; 29:1123-1132.

20. Soverini S, Bavaro L, De Benedittis C, Martelli M, Iurlo A, Orofino N, et al. Prospective assessment of NGS-detectable mutations in CML patients with nonoptimal response: the NEXT-in-CML study. Blood. 2020; 135:534-541.

21. Cortes J, Lomaia E, Turkina A, Moiraghi B, Undurraga Sutton $\mathrm{M}$, et al. Interim analysis from the OPTIC trial - a dose-ranging study of 3 starting doses of ponatinib. Clin Lymph Myel \& Leuk. 2020; 20: S234-S234.

22. Hehlmann R, Berger U, Pfirrmann M, Heimpel H, Hochhaus A, Hasford J, et al. Drug treatment is superior to allografting as first-line therapy in chronic myeloid leukemia. Blood. 2007; 109(11): 4686-4692.

23. Gratwohl A, Pfirrmann M, Zander A, Kröger N, Beelen D, Novotny J, et al. Long-term outcome of patients with newly diagnosed chronic myeloid leukemia: a randomized comparison of stem cell transplantation with drug treatment. Leukemia. 2016; 30(3): 562-569.

24. Fabarius A, Kalmanti L, Dietz CT, Lauseker M, Rinaldetti S, Haferlach C, et al. SAKK and the German CML Study Group. Impact of unbalanced minor route versus major route karyotypes at diagnosis on prognosis of CML. Ann Hematol. 2015;94(12):2015-2024. 
25. Wang W, Cortes JE, Tang G. Risk stratification of chromosomal abnormalities in chronic myelogenous leukemia in the era of tyrosine kinase inhibitor therapy. Blood. 2016; 127(22):2742-2750.

26. Gong Z, Medeiros LJ, Cortes JE, et al. Cytogenetics-based risk prediction of blastic transformation of chronic myeloid leukemia in the era of TKI therapy. Blood Adv. 2017; 1:25412552.

27. Koptyra M, Falinski R, Nowicki MO, Stoklosa T, Majsterek I et al. BCR/ABL kinase induces self-mutagenesis via reactive oxygen species to encode imatinib resistance. Blood. 2006; 108(1): 319-327.

28. Ko TK, Javed A, Lee KL, Pathiraja TN, Liu X, Malik S, et al. An integrative model of pathway convergence in genetically heterogeneous blast crisis chronic myeloid leukemia. Blood. 2020;135(26):2337-2353.

29. Rousselot P, Huguet F, Rea D, Legros L, Cayuela JM, Maarek $\mathrm{O}$, et al. Imatinib mesylate discontinuation in patients with chronic myelogenous leukemia in complete molecular remission for more than 2 years. Blood. 2007; 109(1): 58-60.

30. Mahon FX, Réa D, Guilhot J, Guilhot F, Huguet F, Nicolini $\mathrm{F}$, et al. Discontinuation of imatinib in patients with chronic myeloid leukemia who have maintained complete molecular remission for at least 2 years: the prospective, multicenter Stop Imatinib (STIM) trial. Lancet Oncol. 2010; 11(11), 1029-1035.

31. Saussele S, Richter J, Guilhot J, et al. Discontinuation of tyrosine kinase inhibitor therapy in chronic myeloid leukemia (EURO-SKI): a prespecified interim analysis of a prospective, multicenter, non-randomized, trial. Lancet Oncol. 2018;19(6): 747-757.

32. Rousselot P, Charbonnier A, Cony-Makhoul et al. Loss of major molecular response as a trigger for restarting tyrosine kinase inhibitor therapy in patients with chronic-phase chronic myelogenous leukemia who have stopped imatinib after durable undetectable disease. J Clin Oncol. 2014;32(5): 424-430.

33. Etienne G, Guilhot J, Rea D, Rigal-Huguet F, Nicolini F, Charbonnier A et al. Long-term follow-up of the French Stop Imatinib (STIM1) study in patients with chronic myeloid leukemia. J Clin Oncol. 2017; 35(3): 298-305.

34. Ross DM, Branford S, Seymour JF, Schwarer AP, Arthur C, Yeung DT et al (2013). Safety and efficacy of imatinib cessation for CML patients with stable undetectable minimal residual disease: results from the TWISTER study. Blood. 2013; 122(4): 515-522.

35. Lee SE, Choi SY, Song HY, Kim SH, Choi MY, Park JS et al. Imatinib withdrawal syndrome and longer duration of imatinib have a close association with a lower molecular relapse after treatment discontinuation: the KID study. Haematologica. 2016; 101(6): 717-723.

36. Zang DY, Lee WS, Mun YC, et al. Long-term follow-up after treatment discontinuation in patients with chronic myeloid leukemia: the Korean Imatinib Discontinuation (KID) study. Blood. 2018; 132(Supplement 1): 4252-4252.
37. Nicolini FE, Dulucq S, Guilhot J, Etienne G, Mahon FX. The evaluation of residual disease by digital PCR and TKI duration are critical predictive factors for molecular recurrence after stopping imatinib first-line in chronic phase CML patients: Results of the STIM2 Study. Blood. 2018; 132; ASH abstract 462 .

38. Mori S, Vagge E, Le Coutre P et al. Age and dPCR can predict relapse in CML patients who discontinued imatinib: The ISAV study. Am J Hematol. 2015; 90(10): 910-914.

39. Mori S, le Coutre P, Abruzzese E, et al. Imatinib Suspension and Validation (ISAV) study: final results at 79 months. Blood. 2018; 132(Supplement 1): 461-461.

40. Rea D, Nicolini FE, Tulliez M et al. Discontinuation of dasatinib or nilotinib in chronic myeloid leukemia: interim analysis of the STOP 2G-TKI study. Blood. 2017; 29(7): 846854.

41. Imagawa J, Tanaka H, Okada $\mathrm{M}$ et al. Discontinuation of dasatinib in patients with chronic myeloid leukemia who have maintained deep molecular response for longer than 1 year (DADI trial): a multicenter phase 2 trial. Lancet Haematol. 2015; 2(12): e528-e535.

42. Kadowaki N, Kawaguchi T, Kuroda J et al. Discontinuation of nilotinib in patients with chronic myeloid leukemia who have maintained deep molecular responses for at least 2 years: a multicenter phase 2 stop nilotinib (Nilst) trial. Blood 2016; 128 (ASH Abstracts): 790-790.

43. Kim DDH, Bence-Bruckler I, Forrest DL et al. Treatment-free remission accomplished by dasatinib (TRAD): Preliminary results of the Pan-Canadian tyrosine kinase inhibitor discontinuation trial. Blood. 2016; 128 (ASH Abstracts): 1922-1922.

44. Shah N, García-Gutiérrez JV, Jiménez-Velasco A et al. Dasfree 2-year update: dasatinib discontinuation in patients (pts) with chronic myeloid leukemia in chronic phase (CML-CP) and deep molecular response (DMR): PF408. HemaSphere. 2019; 3: 156.

45. Hughes TP, Boquimpani CM, Takahashi N et al. Treatment-free remission in patients with chronic myeloid leukemia in chronic phase according to reasons for switching from imatinib to nilotinib: subgroup analysis from ENESTop. Blood. 2016; 128 (ASH Abstracts): 792-792.

46. Takahashi N, Nishiwaki K, Nakaseko C et al. Treatment-free remission after two-year consolidation therapy with nilotinib in patients with chronic myeloid leukemia: STAT2 trial in Japan. Haematologica. 2018; 103(11): 1835-1842.

47. Hochhaus A, Masszi T, Giles FJ, Radich JP, Ross DM, Gómez Casares MT et al. Treatment-free remission following frontline nilotinib in patients with chronic myeloid leukemia in chronic phase: results from the ENESTfreedom study. Leukemia. 2017;31(7): 1525-1531.

48. Kumagai T, Nakaseko C, Nishiwaki K et al. Discontinuation of dasatinib after deep molecular response for over 2 years in patients with chronic myelogenous leukemia and the unique profiles of lymphocyte subsets for successful discontinuation: a prospective, multicenter Japanese trial (D-STOP Trial). Blood. 2016; 128 (ASH Abstracts): 791-791. 
49. Hernández-Boluda JC, Pereira A, Pastor-Galán I, Alvarez-Larran A, Savchuk A, Puerta Puerta JM et al. Feasibility of treatment discontinuation in chronic myeloid leukemia in clinical practice: results from a nationwide series of 236 patients. Blood Cancer Journal. 2018; 8(10):1-8.

50. Clark RE, Polydoros F, Apperley J F, Milojkovic D, Rothwell K, Pocock C. Initial reduction of therapy prior to complete treatment discontinuation in chronic myeloid leukaemia: final results of the British DESTINY Study. Lancet Haematol. 2019;6:e375-e383.
51. Rousselot P, Loiseau C, Delord M, Cayuela JM, Spentchian $\mathrm{M}$. Late molecular recurrences in patients with chronic myeloid leukemia experiencing treatment-free remission. Blood Adv. 2020; 4(13): 3034-3040.

52. Legros L, Nicolini FE, Etienne G, Rousselot P, Rea D, Giraudier $\mathrm{S}$ et al. Second tyrosine kinase inhibitor discontinuation attempt in patients with chronic myeloid leukemia. Cancer. 2017; 123(22), 4403-4410.

\section{Новые рекомендации ELN по лечению хронического миелоидного лейкоза. Ранняя трансплантация у пациентов с дополнительными хромосомными аберрациями высокого риска}

\section{Рюдигер Хельманн}

Медицинский факультет Маннгейма, Гейдельбергский университет; Фонд ELN, Вайнхайм, Германия

\section{Резюме}

Через 150 лет после, главным образом, паллиативной терапии хронического миелоидного лейкоза (ХМЛ), успехи лечения ингибиторами тирозинкиназы BCRABL1 (ИТК) привели к нормальным показателям выживаемости большинства пациентов с ХМЛ. Новой целью лечения является достижение ремиссии без лечения (РБЛ) с хорошим качеством жизни без пожизненной терапии. Европейская организация LeukemiaNet (ELN) учитывает эти разработки в своих свежих рекомендациях. Трансплантация гемопоэтических клеток (ТГСК) сохраняет важную роль в лечении пациентов с резистентностью или непереносимостью ИТК или прогрессированием заболевания в более агрессивную фазу. Данный обзор сосредоточен на рекомендациях ELN-2020 по лечению ХМЛ и ранней ТГСК у пациентов высокого риска.

\section{Ключевые слова}

Хронический миелоидный лейкоз, группы высокого риска, ингибиторы тирозинкиназы, трансплантация гемопоэтических стволовых клеток, рекомендации ELN. 